\title{
The Role of Biogas for Economic Sustainability in Nepal: User's Perspective
}

\author{
Maheshwar Prasad Yadav ${ }^{1}$ \\ ${ }^{1} \mathrm{PhD}$ Scholar, Mewar University, Rajasthan, India \\ mpyadav2006@gmail.com
}

\begin{abstract}
Background: Economic sustainability is an important ingredient of sustainable development. Sustainable development is the positive changes in a pattern of resources use in such a way that present needs can be met without destroying the ability for the future generations to meet their needs. Furthermore, renewable energy as an essential ingredient of environment comes from resources which are continually replenished. Renewable energy technologies such as biogas, solar and micro-hydro are widely promoted in Nepal and biogas only considered for this study. Objective: To examine role of biogas for economic sustainability in Nepal based on a case study of Niglihawa VDC of Kapilvastu district. Methodology: This study consists of descriptive cum analytical research design and based on both primary and secondary data. The users' perspectives of sixteen out of twenty two biogas users have been collected by using structured questionnaire. Moreover, the simple statistical techniques of analysis such as table, percentage, and graphs have been employed in this study. Results: Biogas is an important factor in relation to enterprises and employment through saving time and creating agro-based micro enterprises. Biogas also contributes for economic activities through utilizing bio-slurry as feed and fertilizer. Conclusion: Biogas plays the vital role for the economic sustainability through creating enterprises and employment as well as utilizing bio-slurry as fish meal and fertilizer in the context of Nepal in one way or another. The results may be varied in other area and/or sector of Nepal and beyond.
\end{abstract}

KEYWORDS: Biogas, Economic Sustainability, Users' Perspective

\section{INTRODUCTION}

Development is the process of developing or being developed (www.google.com.np: 14 Jan 2014) (www.google.com.np: 14 Jan 2014). It is also known as evolution, growth, maturing, expansion, enlargement, spread, build out, progress, success, blossoming, blooming, burgeoning, headway. It means that positive changes are regarded as development. Moreover, development consists of the process of economic and social transformation that is based on complex cultural and environmental factors and their interactions.

Moreover, the sustainable development recognizes that growth must be both inclusive and environmentally sound to reduce poverty and build shared prosperity for today's population and to continue to meet the needs of future generations (World Bank: 14 Jan 2014). It is efficient with resources and carefully planned to deliver both immediate and long-term benefits for people, planet, and prosperity. The sustainable development ties together concern for the carrying capacity of natural systems with the social and economic challenges faced by humanity. The concept of sustainable development has in the past most often been broken out into three constituent domains: environmental sustainability, economic sustainability and social sustainability. On the other hand, the United Nations 2005 World Summit Outcome Document refers to the "interdependent and mutually reinforcing pillars" of sustainable development as 
economic development, social development, and environmental protection (Wikipedia: 14 Jan 2014). This study has based on economic sustainability out of these three pillars.

Furthermore, energy is necessary for daily survival (World Commission on Environment and Development, 1987). Energy is an essential ingredient of socio economic development and economic growth (Goldemberg, 1996). Renewable energy is energy that comes from resources which are continually replenished such as sunlight, wind, rain, tides, waves and geothermal heat (Wikipedia: 28 Feb 2013). Reliable and sustainable supply of energy is the basic needs of the people for meaningful life including cooking, lighting and economic activities.

To cope up with the increasing pace of population growth in Nepal, production of food grains need to be increased. For that, more land needed to be used for agriculture. More fertilizers must be used to maintain fertility of soil and enhance the agricultural productivity. These demands make the fuel problem even worse, as new agricultural land must come from the forests. As wood becomes less available, people turn to other fuels, such as dried cattle dung and agricultural residues, which could be used for organic fertilizer.

In such circumstances, Nepal has very high potential to exploit the renewable energy; however, it has not been exploited to the fullest. The energy sector of Nepal is characterized by a very heavy reliance on traditional resources that contribute to more than 85 percent of the total energy consumption (AEPC, 2012, p. 1). Renewable energy technologies such as biogas, solar and micro-hydro are widely promoted in Nepal and biogas only considered for this study. Those non-renewable sources of energy are also taken as traditional sources of energy. The use of renewable energy can reduce the dependency on traditional sources of energy.

Biogas contributes for economic sustainability, environmental sustainability and social sustainability. It plays vital role for creating enterprise $\&$ employment and production of slurry $\&$ compost fertilizer. Health and environment along with friendly surroundings contribute for better enterprise integration. It saves time in each household that improved people's livelihood through starting agro \& forest based micro enterprises such as: cash crops, cattle farming, fish farming, etc. These enterprises contribute for quality of life through livelihood enhancement. Likewise, the slurry \& compost fertilizer produce from biogas that contribute for ago-based enterprise integration.

In this perspective, this study aims to determining role of biogas for economic sustainability in Nepal. The first focus of this study is to examine the role of biogas for quality life through livelihood enhancement by developing micro-enterprises. The second focus of this study is to examine the role of biogas for producing bio-slurry as feed and fertilizer. To sum up, this study deals with the following issues: Does biogas play the role for improving people's livelihood through starting micro enterprises such as: cash crops, cattle farming and fish farming? Is biogas reduced dependency on chemical fertilizer through replacing with compost fertilizer?

The remainder of the paper is organized as follows. Section 2 describes the review of literature while methodology has mentioned in section 3. Section 4 has incorporated empirical results. Section 5 summarizes the results and offers some directions for future research. Finally, section 6 acknowledges all whose write ups or contributions have been used in this study.

\section{REVIEW OF LITERATURE}

There are several studies conducted in this area of biogas and economic sustainability as discussed in the following pages. Sigdel and Das (1990) show the forest conservation and 
economic benefits from the biogas while Keier (1993) study consists of economic benefits, social development, improvement in health and sanitation, and protecting environment.

Likewise, Britt (1994) finds economic benefits while livelihood enhancement through micro enterprises while Adhikari (1996) mentions improvement in quality of life through health and sanitation and reduction of workload of women. These studies support to analyze quality of life and economic sustainability through using biogas.

Additionally, Nepal (2001) finds the vital role of biogas for increment in sanitation and saved time that improves quality life. Karki, Karki, \& Khadka (2002) conclude the increase in crop production and reduction of chemical fertilizer by using biogas. Similarly, White (2005) Study consists of the role of biogas as cleaner and efficient energy for agriculture development that consistent with this study for analyzing quality of life through starting micro enterprises.

In addition, Ghimire (2006) concludes improvement in health and sanitation situation and their social status was raised. It was also found that women were highly benefited by the biogas plant that the overall energy and economic condition had been improved. Subedi (2006) finds the users of biogas have brought the significant improvement in the quality of life and reduction on the work load of women. Timsina (2008) Study comprises time saving after installation of biogas from firewood collection, cooking activities and washing utensils. The use of slurry has increased the production especially maize, paddy and vegetables and the use of chemical fertilizer has been reduced which has helped in saving money. These study reveals that the role of biogas for quality of life on one way or another.

Besides, Nepal (2008) shows social development, economic impacts like saving money of firewood, minimisation of health costs due to health improvements, women participation in the economic works and slurry use for increasing the productivity of farms. Bhattarai (2009) Study consists of the economic benefits and improvement in health and sanitation by using biogas. It also shows the role of biogas for livelihood enhancement. Sharma (2010) comprises the agricultural production had been increased after installation of biogas plants. This study also reveals the improvement in economic condition.

As a final point, Bhandari (2010) finds positive impact of biogas on economic, educational, and many other benefits for the users. A study by Yadav (2014) deals with the enterprise integration with biogas for quality of life through creating enterprises and producing bio-fertilizer. Likewise, Adhikary (2012) deals with green economy in pursuance of sustainable development in Nepal.

Several studies have been conducted in Nepal and abroad reveal that the role of biogas for sustainability. The studies conducted in Nepal either focus on technical aspects or environmental aspects of biogas and less on sociological aspects. The applicability of these facts is yet to be seen in the context of Nepal. In this context, a sociological study of biogas is considerable to investigate. The study then concentrates its attention to assess role of biogas for economic sustainably. Thus, the study on the role of biogas for economic sustainability development may be very rewarding.

\section{DATA AND METHODS}

This study has comprised descriptive cum analytical research design. The study has consisted of both primary and secondary data. The secondary data have been collected from the database of Biogas Sector partnership-Nepal (BSP-Nepal) for the period of 1992/93 to 2012/13. The primary data collected by using structured questionnaire to get opinion of biogas users. All 
relevant research issues translated into questions for field survey 2013. The survey conducted at Ward Number 6 of Niglihawa VDC, Kapilvastu district of Nepal.

Moreover, the study has employed multi-stage sampling to determine sample. The Kapilvastu District and Ward number 6 of Niglihawa VDC have selected based on judgmental sampling. The primary rational behind the selection of this study area is proximity with the forest that makes easier to get genuine information on reduction of deforestation. The secondary rational is uses of both dung cake and firewood before installation of biogas plants by the users. However, the simple random sampling (SRS) method has employed to determine study unit for the study. The plant owner is the study unit for this study. Sixteen out of twenty two biogas users have been selected randomly for the study by applying lottery method. Under which, the name slip of all 22 biogas plants owner was prepared and put together in a box and then pick 16 from them as the sample for the study to get opinion of biogas users. The sample of the study has given in Table 1.

Table 1: Selection of Sample for the Study

\begin{tabular}{|l|l|l|l|}
\hline $\begin{array}{l}\text { Total number of household with } \\
\text { biogas plats in Niglihawa-6, } \\
\text { Kapilvastu }\end{array}$ & $\begin{array}{l}\text { Number of household } \\
\text { with biogas plats } \\
\text { selected for the study }\end{array}$ & $\begin{array}{l}\text { Number of sampled Remarks } \\
\text { household with biogas } \\
\text { plats (\%) }\end{array}$ & \\
\hline 22 & 16 & $72.73 \%$ & \\
\hline
\end{tabular}

Source: The database of BSP-Nepal and field survey 2013

There is 72.73 percent household with biogas plants selected for this study which represents the population of household with biogas plants at Niglihawa-6 of Kapilvastu district. Moreover, the simple statistical techniques of analysis such as table, percentage, and figures have employed in this study. The role of biogas for economic sustainability has been determined through analyzing of biogas in relation to creating enterprises and producing bio-fertilizer.

\section{EMPIRICAL RESULTS \\ Respondents Mix}

The study has collected biogas users' opinion through field survey 2013. The study has taken 16 households with biogas plants as sample of the study as mentioned in Annex-2. The respondents mix is given in Table 2 .

Table 2: Respondents Mix

\begin{tabular}{|c|c|c|c|c|c|c|}
\hline \multirow{3}{*}{$\begin{array}{l}\text { Basis } \\
\text { Gender }\end{array}$} & \multicolumn{6}{|l|}{ Data } \\
\hline & Male & Female & Total & \multicolumn{3}{|l|}{ Remarks } \\
\hline & 14 & 2 & 16 & & & \\
\hline \multirow{2}{*}{ Occupation } & Farmer & Student & Trader & Politician & Cook & Total \\
\hline & 8 & 4 & 2 & 1 & 1 & 16 \\
\hline \multirow[t]{2}{*}{ Education } & $10+2$ & SLC & Barely Literate & Illiterate & Total & Remarks \\
\hline & 4 & 6 & 4 & 2 & 16 & \\
\hline
\end{tabular}

Source: Field survey 2013

The respondents' age are ranged between 22 to 55 years old. The average family size of the respondents is 9.06 . Fourteen out of 16 respondents have $6 \mathrm{~m} 3$ biogas plants while one has $8 \mathrm{~m} 3$ and rest another one has $4 \mathrm{~m} 3$ biogas plant.

In addition, 15 plants out of 16 selected plants are 5 years old while one plant is more than 10 years old. The respondents consist of 14 male and 2 female. The respondents' occupations have 
been comprised of 50 percent farmer, 25 percent student and 12.5 percent trader whereas 6.25 percent politician and 6.25 percent cook. The education mix of the respondents include: 25 percent are 10+2, 37.50 percent are SLC, 25 percent are barely literate and rest 12.50 percent are illiterate.

\section{Biogas in Relation to Enterprises and Employment}

Biogas is important in relation to enterprises and employment through economic empowerment, saving time, and creating agro-based micro enterprises. Fifty percent of respondents were taken loan to construct the plant and paid their loan from sales of crops/animals/vegetable as shown in

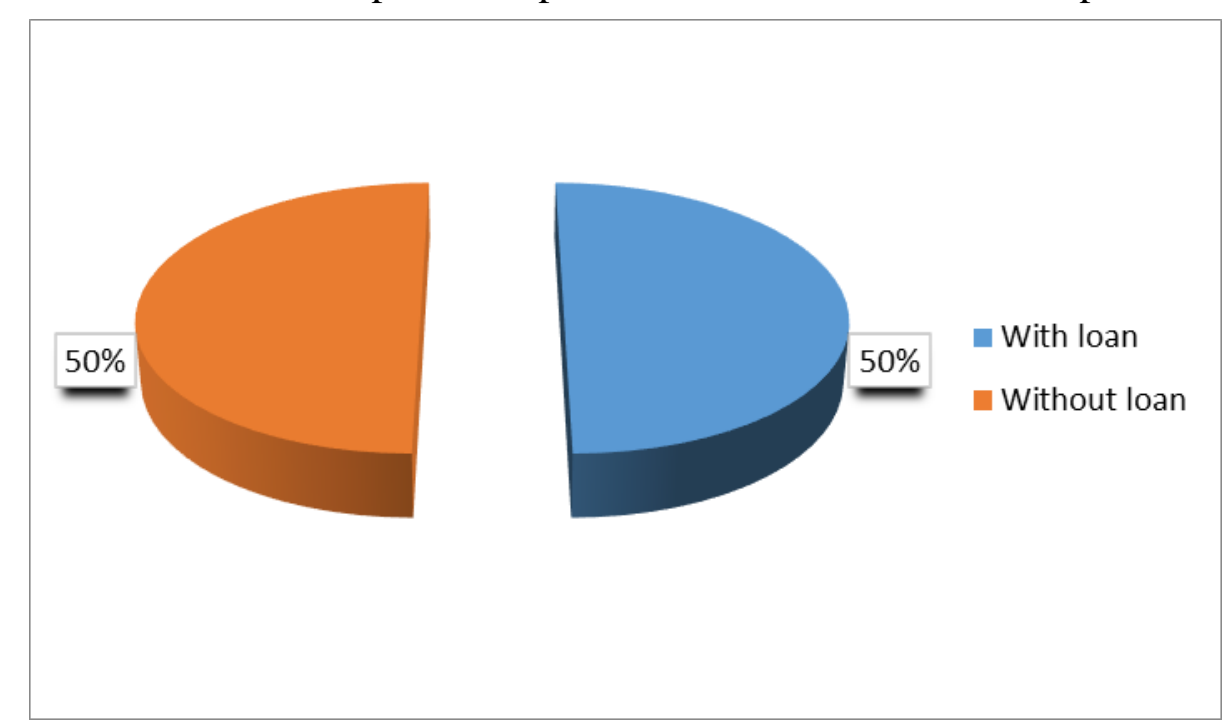

Figure 1.

Figure 1: Biogas Constructed with Loan and without Loan

Source: Field survey 2013

It empowers them to get loan and mobilize it properly along with payment. In addition to this, it also develops saving habits to pay loan after saving for future.

Moreover, 9 out of 16 respondents believed that biogas is not more costly than other sources of energy while 5 respondents think it is the same. One respondent is found to feel that it is costly to others and rest one respondent does not express. Biogas saves time of the rural men and women including children in one way or another. The people of the study area saved 1.844 hours daily from fuel manage of dung cake and firewood while they saved 0.491 hours from cooking. They also saved 0.456 hours from washing utensils daily after construction of biogas. The average time saved per day in aggregate is 2.791 hours after installation of biogas which is slightly lower than the national average time. It saved daily in each household of 3 hours as per Biogas User Survey. The brief description of saving of time is given in Table 3.

Table 3: Saving Time after Installation of Biogas Plant

\begin{tabular}{|l|l|l|l|l|l|}
\hline SN & Works & $\begin{array}{l}\text { Average time saved } \\
\text { per day (in hours) }\end{array}$ & \multicolumn{3}{l|}{ Saving by: } \\
\cline { 5 - 6 } & & & Male & Female & Both \\
\hline 1 & Fuel manage (dung cake or firewood) & 1.844 & 1 & 3 & 12 \\
\hline 2 & Cooking & 0.491 & & 14 & 2 \\
\hline 3 & Washing utensils & 0.456 & & 16 & \\
\hline \hline \multicolumn{2}{|l}{ Total average time saved per day (hours) } & 2.791 & & & \\
\hline
\end{tabular}

Source: Field survey 2013

The saving of time is most often by female as shown in Table 3. It means that it reduces workload of women than that of men. View in this perspective, both male and female are found to involve in fuel manage at great extent but only females are involved in cooking and washing utensils at larger extent. 
The biogas users utilize their saved time for both productive purposes and social work. The people of the study area before installation of biogas plants were also found to involve in farming however; they were found to spend more time in farming after installation of plants. They use their saved time for vegetable farming, cattle farming and shop keeping as shown in Figure 2.
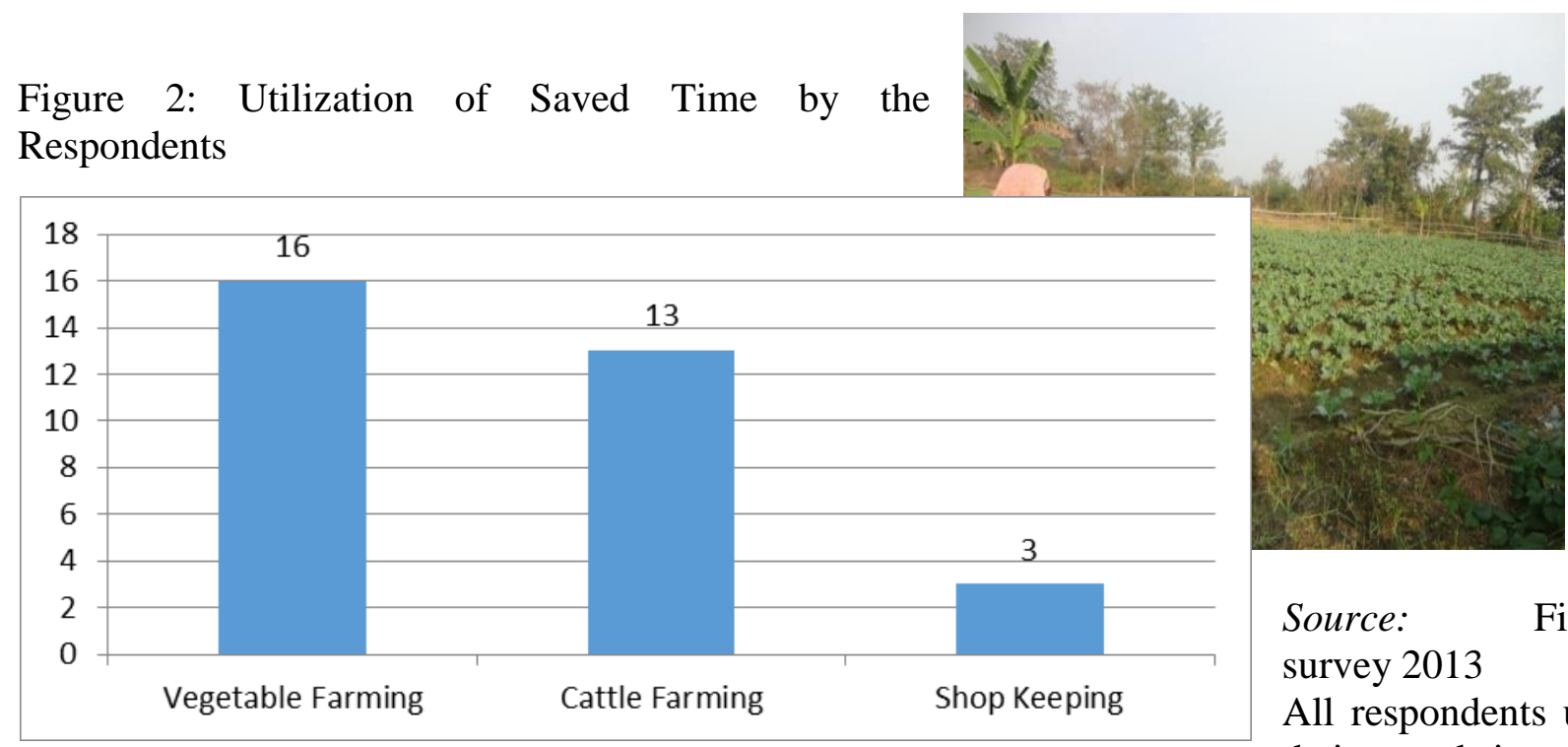

Source: $\quad$ Field survey 2013

All respondents use their saved time for vegetable farming while 13 respondents also use it for cattle farming. Only 3 respondents use their saved time in shop keeping after installation of biogas plant.

Among others, there are some other points in relation to biogas that contribute for quality of life. Biogas is also important in relation to gender role. Women specifically in rural areas of Nepal are confronted with a high workload. They not only work inside the house but also go away to collect fuel wood and fodder. In deforested areas, women are found to spend significant time collecting fuel wood. Besides carrying out almost all domestic works, they are also involved in major part of the agricultural activities in the field. Both men and women are benefited by biogas installation. The benefits are more for women as compared to their workload in household chores. Thus, biogas is an important technology in order to improve social condition of women in the rural areas of Nepal. Furthermore, biogas also saves fuel for the sources of energy that saved money at the end in one way or another. Table 4.4 shows weekly saving amounts.

Table 4: Saving from Consumption of Fuel after Installation Biogas Plants

\begin{tabular}{llll}
\hline SN & Sources of energy & Weekly saved amount (Rs) & \multicolumn{2}{c}{ Remarks } \\
\hline 1 & Firewood & 375.00 & \\
\hline 2 & Dung cake & 184.38 & \\
\hline \multicolumn{7}{l}{ Total saved amounts (NRs.) } & 559.38 & \\
\hline
\end{tabular}

Source: Field survey 2013

The average amounts saved in aggregate in NRs. 559.38 weekly per house consisting of NRs. 375 from firewood and NRs. 184.38 from dung cake. Likewise, the monthly and annual amounts saved have been NRs. 2,237.52 and NRs. 26,850.24 respectively. Thus, it also generates income for the rural people.

Moreover, biogas also plays a great role in reduction in brain drain \& muscle drain and in reduction in migration from rural to urban and beyond. It also provides better rural life through 
available of basic services and improved urban life by managing of urban waste. Biogas contributes for sustainable economic growth by creating enterprises within country and reducing dependency on remittance as well as address energy crisis at larger extent.

View in this perspective, Biogas Construction Company has been involving in plants construction throughout 75 districts of Nepal (BSP-Nepal, 2012). These 107 private Biogas Companies have been strengthened and 17 Biogas appliances manufacturing workshops are developed. Likewise, 264 micro finance institutes got wholesale loan from AEPC's credit fund. Around 13,000 persons have got employment directly, indirectly in this sector (BSP-Nepal, 2012). In addition, there are many NGOs, consulting firms, entrepreneur that are involved in promotion of biogas technology. As the demand for biogas is increasing, employment of skilled and unskilled labour has been increasing every year. Thus, biogas contributes to create enterprises and employment. It improves biogas user's livelihood through starting agro \& forest based micro enterprises by utilizing saved time and bio-slurry such as: cash crops, cattle farming, fish farming, etc.

\section{Figure 3: Utilization of Bio-fertilizer}

Photo by: MP Yadav

\section{Bio-Slurry as Feed and Fertilizer}

Bio-slurry, as one of the outputs of anaerobic digestion system, can profitably be returned to the agricultural system. The close relation between biogas and agriculture can be taken as an indicator of "eco-friendly" nature of the technology. Bio-slurry can be used not only as organic fertilizer or pesticide for crops, but it can also be used as feed for animals like pig, fish, etc.

Bio-slurry has proved to be high quality organic manure rich in humus. It plays an important role in supplying plant nutrients, improving soils, and increase water holding capacity. It is also stabilizing its humid content and preventing the leaching of nutrients. The bio-fertilizers are used to improve the fertility of the land using biological wastes. They are extremely beneficial in enriching the soil with those micro-organisms, which produce organic nutrients for the soil and help combat diseases. The farm produce does not contain traces of hazardous and poisonous materials. Thus those products are accepted across the world as organic ones. Bio-slurry can use as bio-fertilizer after bio-composting while other agro-residuals utilize as bi-fertilizer after processing through bio-char stove.

View in this perspective, the analysis of the primary data shows all the respondents use bioslurry as bio-fertilizer and one respondent also uses it as fish meal. The utilization of bio-slurry in farming is higher as all the respondents are belonging to farming. On the other hand, 10 out of 16 respondents use bio-slurry after composting while rest six respondents use it directly. It means that all the respondents are not fully aware about proper composting of the bio-slurry. The bio-fertilizer has positive role on production of crops as shown in Figure 4. 


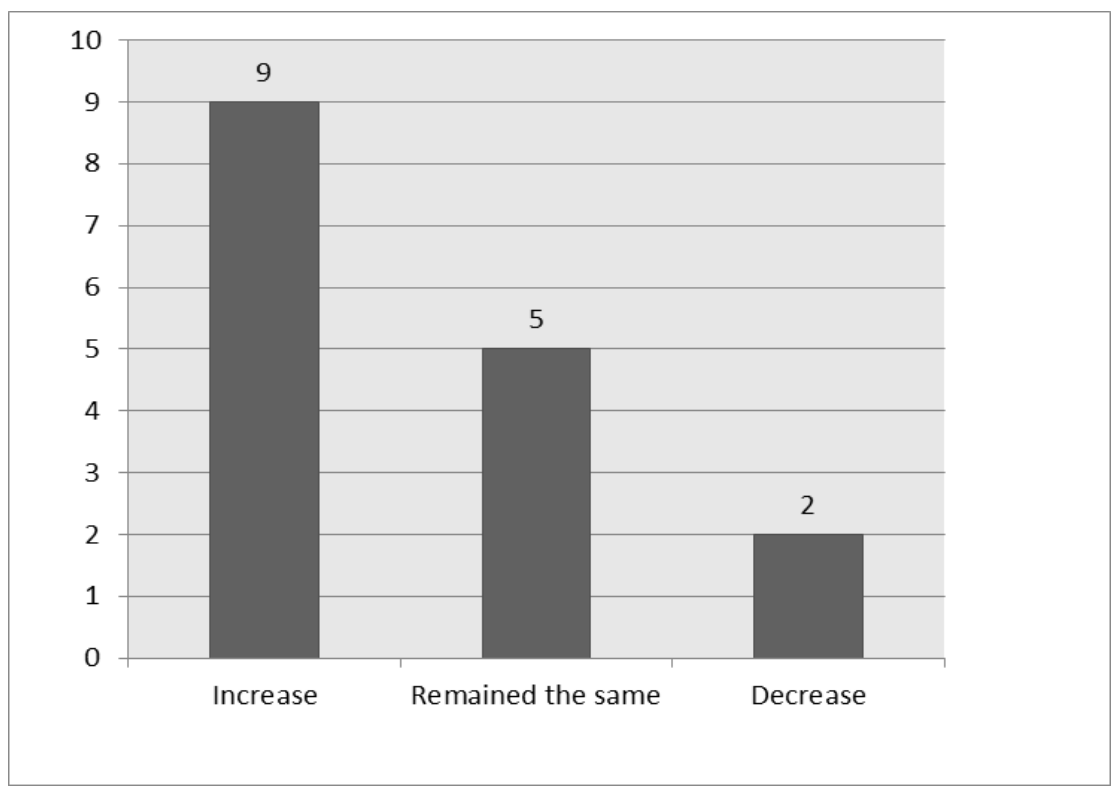

Figure 4: Status of Production after

Installation of Biogas Plants

Source: Field survey 2013

Nine out of sixteen respondents believed that production increased by using bio-slurry while five respondents believed production remained the same. Two respondents think the production decreased somewhat. They believe the nutrients of bio-fertilizer decreased after digested in biogas plants. However, this logic contradicts with the general propositions. On the other hand, the larger number of respondents has expressed that vegetable and paddy increase after using bio-slurry. Ten and eight out of sixteen respondents think production of vegetable and paddy respectively increases by utilizing bio-slurry. One respondent think it increases production of all crops whereas one believes only production of fruits increases by utilizing bio-slurry. In addition to this, there are mix responses on advantages of slurry over dung. Five out of sixteen respondents think it is more effective than dung while four respondents think it is the same as composing of dung. Three respondents think that it does not have advantages while the rest four respondents do not like to say in this regard.

There are 276,357 plants functioning assuming 95 percent plants that are operational as per Biogas User Survey (BSP-Nepal). View in this perspective, there are 1.75 tons slurry \& compost fertilizer annually per household (BSP-Nepal, 2012). In total, there is production of 483,623 tons slurry \& compost fertilizer per year that enhances independency through reduction of chemical fertilizer and fish meal.

\section{CONCLUSION}

The study suggests the existence of the role of biogas for economic sustainability by determining its role for quality of life in relation to micro-enterprises and bio-fertilizer. Based on the analysis of the primary and secondary data, the result reveals the three conclusions respectively. At first, biogas is an important factor in relation to enterprises and employment through saving time and creating agro-based micro enterprises. The average time saved per day per household in aggregate is 2.791 hours after installation of biogas which is slightly lower than 
the national average time saved daily in each household of 3 hours as per Biogas User Survey. They utilize their saved time for vegetable farming, cattle rearing and shop keeping. Biogas also saved fuel for sources of energy that saved money at the end in one way or another. The average amounts saved in aggregate in NRs. 559.38 weekly per house from firewood and dung cake. On the other hand, around 13,000 persons have got employment directly, indirectly in this sector including biogas companies, NGOs, and micro financing institutions throughout Nepal. Second, biogas contributes for economic sustainability through utilizing bio-slurry as feed and fertilizer. Bio-slurry, as one of the outputs of anaerobic digestion system can profitably be returned to the agricultural system as feed and fertilizer. View in this perspective, the results show all the respondents use bio-slurry as bio-fertilizer while only one respondent also uses it as feed for fish. The digested slurry has positive impact on the production of crops. Nine out of sixteen respondents believed that production increased by using bio-slurry while five respondents believed production remained the same. The larger number of respondents has expressed that vegetable and paddy increase after using bio-slurry. On the other hand, there are 1.75 tons slurry \& compost fertilizer annually per household as for national average. In total, there is production of 483,623 tons slurry \& compost fertilizer per year that enhances independency through reduction of chemical fertilizer and fish meal. Finally, biogas plays the vital role for economic sustainability through creating enterprises and employment as well as utilizing bio-slurry as fish meal and fertilizer.

There are several avenues for future research in the area of the role of biogas for sustainable development. First extension of the present study is to use a combination of qualitative and quantitative information extracted from primary and secondary sources of data. A second avenue of research is to conduct a case study by taking a benchmark before installation of biogas and changes after installation biogas to get possibly more concrete results. A third research avenue is to make study by adding additional variables that are correlated with sustainable development to get greater insight into the results. A fourth research avenue is the comparative study of two areas on the role of biogas for sustainable development. A final avenue of research is to survey the opinions of stakeholders other than biogas users on the role of biogas for sustainable development in Nepal.

\section{ACKNOWLEDGEMENTS}

I passionately acknowledge the cooperation received in collecting necessary data from Biogas Sector Partnership Nepal (BSP-Nepal) and all writers and researchers whose write up is used as references for this paper. In this limited space, it is simply impossible to give the names of a large number of friends and well-wishers who have helped me during this work in one way or another. I wish to express the sincerest thanks to them all. I would also like to express debt of gratitude to my family for their continuous support in my efforts. Last but not least, I am equally grateful to the Centre of Excellence for PhD Studies (PhD Centre) for providing an opportunity to publish this article in its Journal of Advanced Academic Research (JAAR).

\section{BIBLIOGRAPHY}

Adhikari, P. (1996). Effects of Biogas Plants on Family Health, Sanitation and Nutrition. Kathmandu.

AEPC. (2012). Annual Progress Report 2010/11. Kathmandu: Alternative Energy Promotion Center, Ministry of Environment, Science and Technology. 
Arthur, R., Baidoo, M. F., \& Antwi, E. (2011). Biogas as a potential renewable energy source: A Ghanaian case study. (A. A. Sayigh, Ed.) Renewable Energy, 36 (5), 1510-1516.

Bhandari, K. (2010). Socio-economic Impact of Biogas Plants: A Case Study of Bungkot VDC of Gorkha District. A Master's Degree Thesis, Tribhuvan University, Central Department of Rural Development, Kathmandu.

Bhattarai, M. (2009). Socio-economic Impact of Biogas Technology in Nepal: A Case Study of Ghorahi Municipality of Dang District. Central Department of Rural Development, Tribhuvan University, Kirtipur, Kathmandu.

Britt, C. (1994). The effect of biogas on women's workloads in Nepal. Lalitpur, Nepal.

BSP-Nepal. (n.d.). Retrieved February 27, 2013, from Biogas Sector Partnership-Nepal (BSPNepal) Web site: http://www.bspnepal.org.np

BSP-Nepal. (2012). BSP Year Book 2011/12. Kathmandu: BSP-Nepal.

Ghimire, T. (2006). Socio-Economic Impact of Biogas Plant in Rural Setting: A Case Study of Shukranagar VDC, Chitwan District, Nepal . Central Department of Rural Development, Tribhuvan University, Kirtipur, Kathmandu .

Goldemberg, J. (1996). Energy, Environment and Development. U.K.: Earthscan.

Karki, A. B., Shrestha, J. N., Bajgain, S., \& Sharma, I. (2009). Biogas as Renewable Source of Energy in Nepal: Theory and Development. Kathmandu: BSP-Nepal.

Karki, B. B., Karki, A. B., \& Khadka, A. (2002). A Study of Renewable Energy Technology with Focus an Income Generating Activities. Final Report , Alternative Energy Promotion Centre (AEPC), Lalitpur, Nepal.

Keier, C. (1993). Effect of Biogas on the Workload of Women from a Gender Perspective. Biogas Support Programme, Kathmandu, Nepal .

Nepal, P. (2008). Socio-economic impact of biogas energy on rural women : a case studay of Chandragadi VDC in Jhapa District . Central Department of Rural Development, Tribhuwan University, Kirtipur, Kathmandu.

New Era. (1995). Biogas Plants in Nepal. Kathmandu.

Sharma, S. (2010). Prospects and Problems of Biogas Plant in Rural Nepal: A Case Study of Devdaha VDC, Rupandehi District, Nepal. Central Department of Rural Development, Tribhuvan University, Kirtipur, Kathmandu.

Subedi, B. R. (2006). Socio-economic impact of biogas plant: a case study of Dhikurpokhari VDC, Kaski District . Kirtipur, Kathmandu: Central Department of Rural Development, Tribhuvan University.

Timsina, D. (2008). Socio-Economic Impact of Biogas Plant in Rural Nepal : A Case Study of Phidim VDC of Panchthar District. Central Department of Rural Development, Tribhuvan University, Kirtipur, Kathmandu.

Wikipedia: 14 Jan 2014. (n.d.). Wikipedia. Retrieved January 14, 2014, from Wikipedia: http://en.wikipedia.org/wiki/Development

Wikipedia: 28 Feb 2013. (n.d.). Retrieved February 28, 2013, from Wikipedia Web site: http://en.wikipedia.org

World Bank: 14 Jan 2014. (n.d.). worldbank. Retrieved January 14, 2014, from http://www.worldbank.org/en/topic/sustainabledevelopment/overview

World Commission on Environment and Development. (1987). Our Common Future. U.K.: Oxford University Press.

www.google.com.np: 14 Jan 2014. (n.d.). Google. Retrieved January 14, 2014, from www.google.com.np 
Yadav, M. P. (2014). Enterprise Integration with Biogas for Quality of Life: A Case of Nepal. Journal of Advanced Academic Research (JAAR), 1 (1), 68-75.

Yadav, M. P. (2012). Role of Biogas for Sustainable Development: A Case of Nepal. Proceeding of International Conference on Operation Research for Sustainable Development. Kathmandu: Operation Research Society of Nepal.

Yadav, M. P. (2011). Role of Key Factors for Biogas Development: A Case of Nepal. The Economic Journal of Nepal , 34 (136), 310-318. 